\title{
Telmisartan-induced sprue-like enteropathy: a case report and a review of patients using non-olmesartan angiotensin receptor blockers
}

\author{
Harshal Surendra Mandavdhare ${ }^{1}$, Vishal Sharma ${ }^{1}$, Kaushal K Prasad ${ }^{1}$, Amit Kumar ${ }^{1}$, Manish Rathi ${ }^{2}$, \\ Surinder S Rana ${ }^{1}$ \\ Departments of ${ }^{1}$ Gastroenterology and ${ }^{2}$ Nephrology, Postgraduate Institute of Medical Education and Research, Chandigarh, India
}

Recent studies have identified sprue-like illness associated with the use of the antihypertensive agent olmesartan medoxomil. However, whether this condition is specific to the use of olmesartan or is associated with the use of drugs belonging to the class of "sartans" remains to be clarified. A 45-year-old woman with chronic kidney disease along with hypothyroidism and hypertension presented with chronic diarrhea and significant weight loss. Endoscopy of the upper gastrointestinal tract showed scalloping and grooving of the duodenum, and histopathological examination showed subtotal villous atrophy. She was on telmisartan for hypertension, which was discontinued. Subsequently, diarrhea ameliorated dramatically, and she regained weight. To our knowledge, this is the first study to report telmisartan-associated sprue-like enteropathy. Further, we have reviewed the cases of patients with sprue-like enteropathy caused by valsartan, irbesartan, and eprosartan. (Intest Res 2017;15:419-421)

Key Words: Celiac disease; Diarrhea; Malabsorption; Angiotensin receptor blockers

\section{INTRODUCTION}

Recent studies have shown that the angiotensin receptor blocker (ARB) olmesartan medoxomil induces a sprue-like illness characterized by diarrhea and malabsorption. ${ }^{1-3}$ This disease affects men and women equally, and most cases have been reported in men and women aged 60 to 80 years. The common presentation of this disease is chronic diarrhea with weight loss, and some patients present with fatigue, nausea, vomiting, abdominal pain, and bloating. Majority of the patients exhibit total or partial villous atrophy, which improves with drug withdrawal. ${ }^{1}$ Several studies have reported sprue-like enteropathy associated with olmesartan; however,

Received August 22, 2016. Revised September 23, 2016. Accepted October 4, 2016. Published online February 21, 2017

Correspondence to Vishal Sharma, Department of Gastroenterology, Postgraduate Institute of Medical Education and Research, Chandigarh 160012, India. Tel: +91-708-7008099, Fax: +91-172-2744401, E-mail: docvishalsharma@gmail.com

Financial support: None. Conflict of interest: None. only 5 cases of patients with sprue-like enteropathy associated with telmisartan, valsartan, irbesartan, and eprosartan have been reported thus far. ${ }^{1,4-8}$ The patient with telmisartaninduced sprue-like enteropathy exhibited ileitis with colitis without the involvement of the duodenum. ${ }^{4}$ To our knowledge, our study has reported telmisartan-induced sprue-like enteropathy involving the duodenum for the first time.

\section{CASE REPORT}

A 45-year-old woman with hypothyroidism and hypertension and a history of chronic kidney disease had presented with chronic diarrhea and weight loss of $10 \mathrm{~kg}$ for the past 8 months. She had anemia, and her hemoglobin level was 10.3 $\mathrm{g} / \mathrm{dL}$; total leukocyte count was $7,600 \times 10^{3} / \mathrm{dL}$; and platelet count was $2.34 \times 10^{3} / \mathrm{dL}$. She also exhibited impaired renal function with BUN and creatinine levels of $67 \mathrm{mg} / \mathrm{dL}$ and $2.1 \mathrm{mg} / \mathrm{dL}$, respectively. She had hypoalbuminemia with an albumin level of $2.7 \mathrm{~g} / \mathrm{dL}$. The results of the liver function

\footnotetext{
(c) Copyright 2017. Korean Association for the Study of Intestinal Diseases. All rights reserved.

This is an Open Access article distributed under the terms of the Creative Commons Attribution Non-Commercial License (http://creativecommons.org/licenses/by-nc/4.0)

which permits unrestricted non-commercial use, distribution, and reproduction in any medium, provided the original work is properly cited.
} 
test were normal, and her total bilirubin level was $0.9 \mathrm{mg} / \mathrm{dL}$; direct bilirubin level was $0.2 \mathrm{mg} / \mathrm{dL}$; aspartate transaminase level was $26 \mathrm{IU} / \mathrm{L}$; alanine transaminase level was $20 \mathrm{IU} / \mathrm{L}$; and ALP level was $117 \mathrm{IU} / \mathrm{L}$. Electrocardiograph showed left ventricular hypertrophy, and the chest radiograph showed no abnormalities. To determine the cause of diarrhea, we performed the routine stool examination and culture, which were noncontributory. Further, the results of serological examination for celiac disease (IgA anti-tissue transglutaminase antibody) were negative. Her upper gastrointestinal

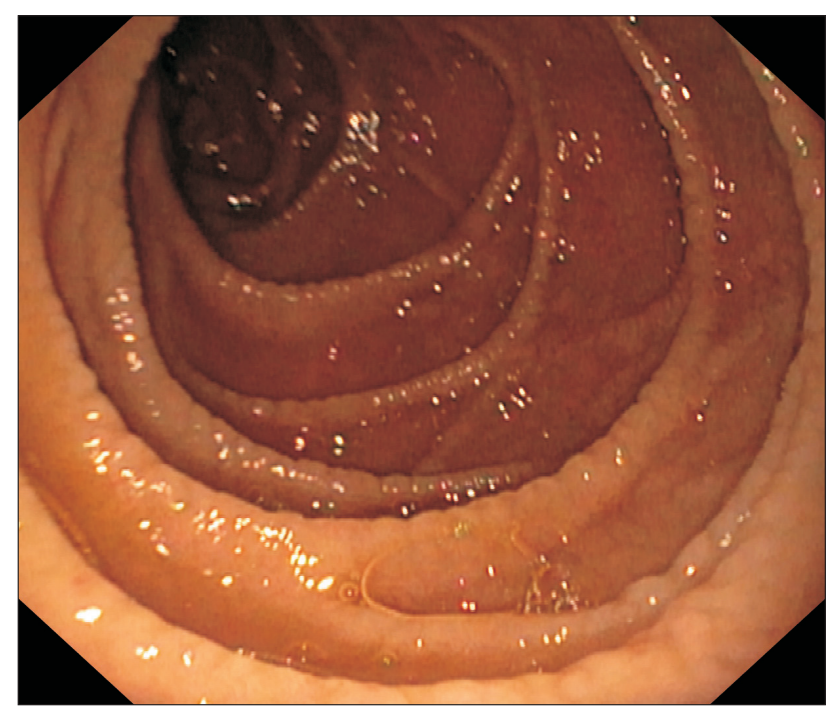

Fig. 1. Mucosa of the duodenum showing grooving and scalloping. endoscopy revealed typical scalloping and grooving with nodularity (Fig. 1). Multiple samples were taken from the second part of the duodenum and biopsy was performed, which showed subtotal atrophy of the duodenal villous pattern (Fig. 2). The patient had been prescribed telmisartan 40 mg daily for hypertension for the past 1 year. After discontinuation of telmisartan and switching to amlodipine, diarrhea subsided, renal function improved, and significant weight gain was observed. Follow-up endoscopy showed normal duodenal folds 4 months after discontinuation of telmisartan.

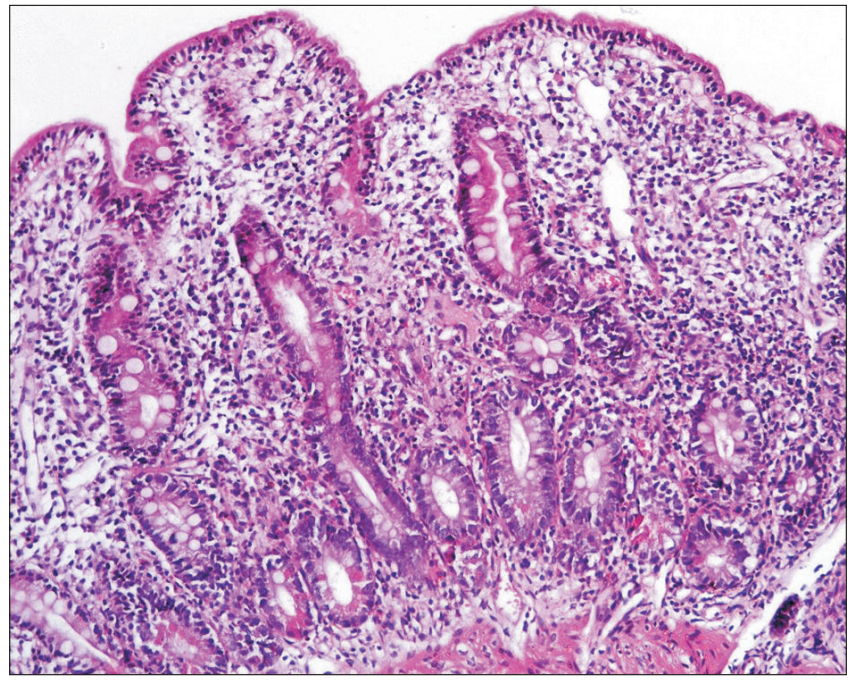

Fig. 2. Subtotal villous atrophy with increased numbers of intraepithelial lymphocytes and crypt hyperplasia $(H \& E, \times 200)$.

Table 1. Report of Non-olmesartan Angiotensin Receptor Blocker-Related Cases of Sprue-Like Enteropathy

\begin{tabular}{|c|c|c|c|c|c|c|c|}
\hline Case & $\begin{array}{l}\text { Age } \\
\text { (yr) }\end{array}$ & Sex & $\begin{array}{l}\text { Causing } \\
\text { drug }\end{array}$ & $\begin{array}{l}\text { Duration of } \\
\text { drug use }\end{array}$ & $\begin{array}{l}\text { Involved } \\
\text { organ }\end{array}$ & Pathologic findings & Clinical outcome \\
\hline Case $1^{4}$ & 71 & Female & Telmisartan & $2 \mathrm{mo}$ & $\begin{array}{l}\text { Colon, ileum, } \\
\text { and stomach }\end{array}$ & $\begin{array}{l}\text { Severe villous atrophy, } \\
\text { intraepithelial lymphocytosis, } \\
\text { subepithelial collagen band in } \\
\text { terminal ileum, colonic, and } \\
\text { stomach biopsies }\end{array}$ & $\begin{array}{l}\text { Symptoms and histology } \\
\text { improved in } 7 \text { mo of stopping } \\
\text { the drug }\end{array}$ \\
\hline Case $3^{8}$ & 54 & Female & Irbesartan & $9 \mathrm{mo}$ & Duodenum & Total villous atrophy & $\begin{array}{l}\text { Clinical improvement after } \\
\text { stopping the drug }\end{array}$ \\
\hline Case $4^{9}$ & 71 & Female & Valsartan & $5 \mathrm{yr}$ & $\begin{array}{l}\text { Duodenum and } \\
\text { jejunum }\end{array}$ & $\begin{array}{l}\text { Complete villous atrophy, } \\
\text { intraepithelial lymphocytosis, } \\
\text { and crypt hyperplasia }\end{array}$ & $\begin{array}{l}\text { Improved after stopping the } \\
\text { drug }\end{array}$ \\
\hline $\begin{array}{l}\text { Present } \\
\text { case }\end{array}$ & 45 & Female & Telmisartan & $1 \mathrm{yr}$ & Duodenum & $\begin{array}{l}\text { Subtotal atrophy of the duodenal } \\
\text { villous pattern }\end{array}$ & $\begin{array}{l}\text { Clinical and histological } \\
\text { improvement }\end{array}$ \\
\hline
\end{tabular}




\section{DISCUSSION}

Several recent studies have reported olmesartan-induced sprue-like enteropathy. ${ }^{1-4}$ A systematic review of 54 cases of olmesartan-induced sprue-like enteropathy showed that $64 \%$ patients were human leukocyte antigen (HLA) DQ2/ DQ8 positive, whereas the incidence of HLA DQ2/DQ8positive individuals is $40 \%$ among the general population; therefore, the involvement of the HLA system in this disease cannot be ruled out. ${ }^{3}$ Interestingly, similar to patients with celiac sprue, some patients with sprue-like enteropathy show a subepithelial collagen band, with one-third having lymphocytic gastritis. ${ }^{2,3}$

The pathogenesis underlying this condition is unclear; however, it is believed that angiotensin II plays a proapoptotic role by acting on angiotensin (AT) 2 receptors in the proximal gut because of selective saturation of AT 1 receptors by sartans; further, impaired interleukin-15 signaling and disruption of the tight junction protein zonula occludens- 1 has been implicated in this condition. ${ }^{9,10}$

A recent study reported the case of a patient with telmisartan-induced collagenous ileitis, colitis, and gastritis; however, this patient showed normal pattern of the duodenal villi on endoscopy of the upper gastrointestinal tract, and biopsy of the duodenum showed no abnormalities. ${ }^{4}$ A previous study has shown sprue-like enteropathy associated with irbesartan and valsartan. ${ }^{1}$

To our knowledge, this is the first study to report on the association between telmisartan and sprue-like enteropathy involving the duodenum. The cases of patients with spruelike enteropathy caused by ARBs belonging to the sartan class other than olmesartan are shown in Table $1 .^{4-8}$ Our results indicate that sprue-like enteropathy is associated with the sartan class of ARBs rather than a single drug. Therefore, the possibility of sprue-like enteropathy should be considered as a differential diagnosis in patients who receive antihypertensives belonging to the sartan class, develop newonset diarrhea, undergo weight loss, or show features of malabsorption.

\section{REFERENCES}

1. Choi EY, McKenna BJ. Olmesartan-associated enteropathy: a review of clinical and histologic findings. Arch Pathol Lab Med 2015;139:1242-1247.

2. Burbure N, Lebwohl B, Arguelles-Grande C, Green PH, Bhagat G, Lagana S. Olmesartan-associated sprue-like enteropathy: a systematic review with emphasis on histopathology. Hum Pathol 2016;50:127-134.

3. Ianiro G, Bibbò S, Montalto M, Ricci R, Gasbarrini A, Cammarota G. Systematic review: sprue-like enteropathy associated with olmesartan. Aliment Pharmacol Ther 2014;40:16-23.

4. Cyrany J, Vasatko T, Machac J, Nova M, Szanyi J, Kopacova M. Letter: telmisartan-associated enteropathy: is there any class effect? Aliment Pharmacol Ther 2014;40:569-570.

5. Cammarota G, Ianiro G, Bibbò S, Gasbarrini A. Letter: telmisartan associated enteropathy: is there any class effect? Authors' reply. Aliment Pharmacol Ther 2014;40:570.

6. Marthey L, Cadiot G, Seksik P, et al. Olmesartan-associated enteropathy: results of a national survey. Aliment Pharmacol Ther 2014;40:1103-1109.

7. Herman ML, Rubio-Tapia A, Wu TT, Murray JA. A case of severe sprue-like enteropathy associated with valsartan. ACG Case Rep J 2015;2:92-94.

8. Maier H, Hehemann K, Vieth M. Celiac disease-like enteropathy due to antihypertensive therapy with the angiotensin-II receptor type 1 inhibitor eprosartan. Cesk Patol 2015;51:87-88.

9. Sun L, Wang W, Xiao W, Liang H, Yang Y, Yang H. Angiotensin II induces apoptosis in intestinal epithelial cells through the AT2 receptor, GATA-6 and the Bax pathway. Biochem Biophys Res Commun 2012;424:663-668.

10. Marietta EV, Nadeau AM, Cartee AK, et al. Immunopathogenesis of olmesartan-associated enteropathy. Aliment Pharmacol Ther 2015;42:1303-1314. 